DOI: $10.17951 / \operatorname{lrp} .2019 .38 .1 .23-40$

\author{
AgNieszKa WeINER \\ Wyższa Szkoła Ekonomii i Innowacji Lublin \\ Wydział Nauk o Człowieku \\ Zakład Dydaktyki i Kształcenia Nauczycieli \\ https://orcid.org/0000-0001-5687-5090
}

\title{
BADANIE JAKO AKT TWÓRCZY - REFLEKSJE NA MARGINESIE RAPORTU Z OGÓLNOPOLSKICH BADAŃ KOMPETENCJI MUZYCZNYCH ABSOLWENTÓW I ETAPU EDUKACYJNEGO
}

Streszczenie: Artykuł prezentuje refleksje badawcza w odniesieniu do rezultatów największego jak dotąd w Polsce, ostatnio zrealizowanego projektu, diagnozującego kompetencje muzyczne uczniów etapu wczesnoszkolnego. Autorka z pozycji kierownika naukowego projektu interpretuje uzyskane wyniki w kontekście wieloletnich trendów, zaś samo badanie traktuje jako akt twórczy, którego początek stanowi pytanie, a koniec zrozumienie.

Słowa kluczowe: Wczesna edukacja, kompetencje muzyczne, badanie jako akt twórczy

\section{WPROWADZENIE}

Pierwsze lata dziecka w szkole cieszą się od dawna dużym zainteresowaniem badaczy. Etap ten stał się na przestrzeni ostatniej dekady przedmiotem ostrych sporów społecznych i zmian prawnych ( chociażby w zakresie wieku startu szkolnego).

Edukacja muzyczna realizowana jest w klasach początkowych obligatoryjnie, przed rokiem 1999/2000 $\mathrm{w}$ ramach przedmiotowego, a obecnie $\mathrm{w}$ ramach zintegrowanego modelu kształcenia. Jej status - uznanego powszechnie przedmiotu obowiązkowego - nie przekłada się niestety w sposób automatyczny ani na znaczenie muzyki w procesie kształcenia ani, tym bardziej, na poziom osiągnięć uczniów.

Trend badawczy uzasadniający konieczność lokowania muzyki w ogólnokształcących programach szkolnych ma już swoją historię i dotyczy wszystkich 
kontynentów (Weiner 2010, s. 103-158). W Polsce, która jako jeden z nielicznych krajów na świecie, posiada państwowy system specjalistycznego szkolnictwa muzycznego, poziom powszechnej muzycznej edukacji powinien być co najmniej dobry.

Tymczasem stan kompetencji muzycznych dzieci ze szkół ogólnokształcących, pomimo kolejnych reform oświatowych, systematycznie obniża się. Wskazują na to wyniki badań podejmowanych na przestrzeni wielu lat przez badaczy zainteresowanych tym obszarem (Jaworska 1991; Dyląg 1994; Burowska i in. 1997; Hoffman-Lipska, Żychowska 1997; Zwolińska 1997; Weiner 2000; 2004; 2006; 2008; 2010; 2016; Suświłło 2001; Sacher 2004; Rakowski 2010; Kamińska 2016 i in.). Biorąc pod uwagę, iż etap wczesnoszkolny w odniesieniu do większości dyspozycji muzycznych jest okresem krytycznym, nie można dopuścić do sytuacji aby okazał się straconym dla muzycznego rozwoju.

Aby przekonać się jaka jest rzeczywista skala powyższego problemu Instytut Muzyki i Tańca wyszedł w 2016 roku z inicjatywą ogólnopolskiego projektu badań poziomu kompetencji muzycznych uczniów klas początkowych. Warto zwrócić uwagę na skalę przedsięwzięcia: wyniki zebrano ze 150 szkół (ulokowanych we wszystkich województwach kraju) i od tyluż nauczycieli wychowawców, przetestowano łącznie 2863 uczniów (47,2\% dziewcząt i 48,1\% chłopców) a aż 80 osób zaangażowanych było w proces zbierania danych.

\section{DECYZJE METODOLOGICZNE}

Badania w zakresie edukacji artystycznej (w tym muzycznej) odnoszą się na ogół do dwóch dziedzin, którym towarzyszą swoiste „tradycje” badań i praktyki - nauk humanistycznych, w tym nauki o sztuce (Dz.U. $2011 \mathrm{nr} 179$ poz. 1065') i nauk społecznych. Każda z nich w ostatnich latach przeszła istotne przeobrażenia. Nauki humanistyczne stały się bardziej interdyscyplinarne, na co wpływało stopniowe zacieranie się granic poszczególnych dyscyplin. Z kolei w obrębie nauk społecznych badania objęły postpozytywizm i konstruktywizm.

Ujmowanie pedagogiki muzyki w perspektywie szerokiego, socjokulturowego kontekstu stało się zauważalne już w latach dziewięćdziesiątych ubiegłego wieku. Rozmiękczaniu granic pomiędzy dyscyplinami towarzyszyła hybrydyzacja metodologii, co skutkowało nasilonym krzyżowaniem się i przekraczaniem sfer artystycznych i intelektualnych. Niezależnie jednak od podjętych decyzji metodologicznych, samo badanie zawsze pozostaje aktem twórczym, którego początek stanowi pytanie, a koniec zrozumienie.

\footnotetext{
${ }^{1}$ Nowy projekt rozporządzenia z dnia 31 lipca $2018 \mathrm{r}$ modyfikuje ten układ.
} 
Przedmiot badań omawianego projektu (Weiner, Waluga i in. 2016), zgodnie ze światowym trendem, usytuowano na pograniczu dyscyplin oraz na pograniczu etapów edukacyjnych, uwzględniając dwa kluczowe elementy procesu dydaktycznego: ucznia i nauczyciela. Interesował nas jako badaczy nie tylko poziom kompetencji muzycznych absolwentów I etapu edukacyjnego. Chcieliśmy uchwycić również zależności pomiędzy osiągnięciami dzieci a ważnymi, naszym zdaniem, zmiennymi ulokowanymi w zasobach osobistych badanych osób - uczniów i nauczycieli. Podjęte przez nas decyzje warunkowane były oczywiście czasem i środkami finansowymi jakie mieliśmy do dyspozycji, ale przede wszystkim - samą materią merytoryczną.

Ostatecznie, poszukując odpowiedzi na pytanie dotyczące poziomu kompetencji muzycznych dzieci, które kończą etap nauczania początkowego skoncentrowaliśmy się na diagnozie percepcyjnych umiejętności muzycznych. Nie znaczy to, iż inne obszary nas nie interesowały, albo że uznaliśmy je za mniej ważne. Wybór nasz podyktowany był istotnymi przesłankami - chodziło o sprawne zebranie twardych danych, które wykazałyby czy rzeczywiście wczesna edukacja muzyczna w obecnym, realizowanym w szkole ogólnokształcącej, kształcie nie rozwija potencjału dzieci będących w najlepszym dla takich działań okresie.

Rozpoznanie realizowane trafnym i rzetelnym narzędziem na dobranej reprezentatywnej ogólnopolskiej próbie gwarantowało dostęp do wyników mocno zbliżonych do rzeczywistości, co było naszym priorytetem. Decyzje, odnośnie wyboru metody badań (sondaż diagnostyczny) oraz technik (testowanie, ankietyzacja, skalowanie) pozwoliły z kolei na zebranie odpowiedniej ilości informacji oraz na wpisanie się w najlepszy możliwy sposób w czasowy rygor projektu.

Posiadając dobre wyjściowe rozpoznanie w zakresie przedmiotu naszych badań uznaliśmy za istotne także zebranie danych o aktywności muzycznej badanych dzieci, gdyż to od niej głównie zależą muzyczne kompetencje. Uznaliśmy, iż 9 -10 - latki mogą z powodzeniem same nas o tym poinformować. Poprosiliśmy więc o ich deklaracje, stosując sprawdzone wcześniej w innych badaniach narzędzie skalę AMD (Weiner 2010, s.182-202).

Nie mogliśmy oczywiście odnieść się wyłącznie do uczniów, gdyż osobą odpowiedzialną za edukację muzyczną w szkole pozostaje nauczyciel. Jest to, jak wskazują wyniki naukowych eksploracji (Weiner 2010, s. 345-359), najważniejszy predyktor poziomu kompetencji dzieci z obszaru dydaktycznego, na tyle istotny, iż nie można byłoby go pominąć. Zwróciliśmy się więc do pedagogów (wychowawców) badanych uczniów z prośbą o wypełnienie kwestionariusza ankiety, który również stanowił przetestowane we wcześniejszych badaniach narzędzie.

Mimo tak szeroko zakrojonego zakresu podjętych badań, uznaliśmy nasze działania zaledwie za pierwszy etap diagnozy uczniów klas początkowych. Planujemy w przyszłości kolejne etapy, które uwzględnią przesłuchania indywidualne, 
pozwalające na trafną ocenę kompetencji wykonawczych oraz twórczych dzieci $\mathrm{w}$ wieku wczesnoszkolnym.

\section{MATERIA MERYTORYCZNA - OD PYTANIA DO ZROZUMIENIA}

Uzyskane wyniki pozwoliły zidentyfikować szereg prawidłowości dotyczących zarówno funkcjonowania uczniów jak i nauczycieli w ramach wczesnej edukacji muzycznej. Stały się one również źródłem wniosków i refleksji związanych z muzycznymi umiejętnościami percepcyjnymi, poziomem podejmowanej przez uczniów aktywności oraz zasobami osobistymi badanych nauczycieli. Uporządkowałam je poczynając od bardziej ogólnych, dotyczących doboru próby i terenu badań, poprzez kwestie kompetencji muzycznych uczniów, na wybranych uwarunkowaniach poziomu tych umiejętności kończąc.

\section{PRÓBA BADAWCZA I TEREN BADAŃ}

Dobór terenu badań zaplanowano z największą starannością i z uwzględnieniem wszystkich województw. Jednak mimo wielowarstwowego losowania nie udało się tak dobrać grup (klas) uczniów aby w połowie z nich zajęcia muzyczne realizował muzyk $^{2}$. Wynika to $\mathrm{z}$ faktu, iż sytuacje takie są w praktyce szkolnej rzadkością. Powstała dysproporcja pomiędzy klasami z nauczycielem bez dodatkowego przygotowania muzycznego ${ }^{3}$ odwzorowywała więc rzeczywistość edukacyjną.

\section{POZIOM MUZYCZNYCH UMIEJĘTNOŚCI PERCEPCYJNYCH}

Badani uczniowie uzyskali ogółem w Teście Muzycznych Umiejętności Percepcyjnych średnią arytmetyczną $\mathrm{M}=23,25$ punktów, a wartość odchylenia standardowego wyniosła $\mathrm{SD}=4,38$. W 2007 roku uczniowie klas trzecich (badani tym samym testem) uzyskali średni wynik $\mathrm{M}=24,33$ punktu a ich rozsiew ich wyników wyniósł SD = 5,48 (Weiner, 2007, s. 73). Natomiast w roku 2010 (Weiner) średni wynik wyniósł $\mathrm{M}=23,10$ a odchylenie standardowe $\mathrm{SD}=4,37$.

\footnotetext{
${ }^{2}$ Nauczyciel specjalista edukacji artystycznej w zakresie sztuki muzycznej, realizujący muzykę w starszych klasach szkoły podstawowej.

${ }^{3}$ Oczywiście na etapie kształcenia w uczelni wyższej studenci edukacji wczesnoszkolnej otrzymują przygotowanie także z zakresu edukacji muzycznej.
} 
Różnice, na pierwszy rzut oka, nie wydają się duże ale zauważalna jest tendencję do ich obniżania się. Stwierdzona już w 2007 roku róznica pomiędzy wynikami chłopców i dziewcząt na korzyść tych ostatnich nadal się utrzymuje, podobnie jak rozsiew wyników w obrębie płci, które w przypadku chłopców osiąga nieco wyższą wartość. Dane wskazują, iż dziewczęta w tym wieku nieco lepiej radzą sobie z zadaniami Testu Muzycznych Umiejętności Percepcyjnych (TMUP) oraz stanowią mniej zróżnicowaną grupę.

Poszczególne podtesty TMUP zawierają różne zadania słuchowe. Odnoszą się one do kilku obszarów muzycznej percepcji: konstrukcji dzieła muzycznego, brzmienia, znaczenia i emocji oraz stylu. W różny także sposób znajdują powiązanie z typowo szkolnymi muzycznymi treściami.

Tabela 1. Umiejętności percepcyjne badane testem

\begin{tabular}{|c|c|c|c|c|}
\hline Umiejętności percepcyjne & $\begin{array}{l}\text { Numer } \\
\text { zadania }\end{array}$ & $\begin{array}{l}\text { Liczba } \\
\text { zadań }\end{array}$ & $\begin{array}{l}\text { Liczba } \\
\text { itemów }\end{array}$ & Punktacja \\
\hline \multicolumn{5}{|l|}{$\begin{array}{l}\text { Część I } \\
\text { Percepcja elementów konstrukcyjnych utworu }\end{array}$} \\
\hline $\begin{array}{l}\text { 1. Percepcja struktur wysokościowych } \\
\text { 2. Percepcja struktur czasowych (metrum) } \\
\text { 3. Percepcja struktur czasowych (tempo) } \\
\text { 4. Powtarzalność motywów } \\
\text { 5. Harmonia } \\
\text { - tonalność (tryb) } \\
\text { - finalność } \\
\text { 6. Budowa formalna utworu }\end{array}$ & $\begin{array}{c}1,2 \\
5 \\
7 \\
3 \\
6 \\
8 \\
4\end{array}$ & $\begin{array}{l}2 \\
1 \\
1 \\
1 \\
1 \\
1\end{array}$ & $\begin{array}{l}4 \\
2 \\
2 \\
2 \\
2 \\
3 \\
2\end{array}$ & $\begin{array}{l}4 \\
2 \\
2 \\
2 \\
2 \\
3 \\
2\end{array}$ \\
\hline Razem & & 8 & 17 & 17 \\
\hline \multicolumn{5}{|l|}{$\begin{array}{l}\text { Część II } \\
\text { Tożsamość w muzyce, wrażliwość na styl }\end{array}$} \\
\hline $\begin{array}{l}\text { 1. Postrzeganie tożsamości w przebiegu muzycznym } \\
\text { 2. Wrażliwość na styl }\end{array}$ & $\begin{array}{l}1,2,3,4,5 \\
6,7\end{array}$ & $\begin{array}{l}5 \\
2\end{array}$ & $\begin{array}{c}10 \\
4\end{array}$ & $\begin{array}{c}10 \\
4\end{array}$ \\
\hline Razem & & 7 & 14 & 14 \\
\hline \multicolumn{5}{|l|}{$\begin{array}{l}\text { Część III } \\
\text { Kojarzenie muzyki z treściami pozamuzycznymi, } \\
\text { wrażliwość na brzmienie }\end{array}$} \\
\hline $\begin{array}{l}\text { 1.Kojarzenie muzyki z treściami pozamuzycznymi } \\
\text { 2.Barwa głosów ludzkich i instrumentów muzycznych }\end{array}$ & $\begin{array}{c}1,2,3,4 \\
5,6,7\end{array}$ & $\begin{array}{l}4 \\
3\end{array}$ & $\begin{array}{l}7 \\
7\end{array}$ & $\begin{array}{l}6 \\
7\end{array}$ \\
\hline Razem & & 7 & 14 & 13 \\
\hline Ogółem & & 21 & 45 & 45 \\
\hline
\end{tabular}

We wszystkich częściach TMUP dziewczęta wykazały wyższy poziom umiejętności, podobnie jak w latach wcześniejszych. Tradycyjnie także zadania z zakresu drugiego podtestu sprawdzające umiejętność rozpoznawania tożsamości w muzyce 
i badające wrażliwość na styl okazały się najtrudniejsze (w łącznej ocenie). W dwu pierwszych częściach testu (I - Percepcja elementów konstrukcyjnych utworu i II - Tożsamość w muzyce, wrażliwość na styl) rozwiązano poprawnie znacznie mniej zadań niż w poprzednich latach. W podteście I aktualny wynik to 50,5\% poprawnie rozwiązanych zadań, podczas gdy w 2007 roku badani rozwiązali ich $54 \%$. W podteście II w obecnym sprawdzianie uzyskano $42,2 \%$ poprawnych odpowiedzi podczas gdy poprzednio - 46\%. W podteście III (Kojarzenie muzyki z treściami pozamuzycznymi, wrażliwość na brzmienie) aktualny wynik wynosi $67,3 \%$ poprawnych odpowiedzi, a w poprzednich badaniach $63 \%$. Tak więc już bardzo pobieżna analiza wyników w podtestach wskazuje na odmienną, w stosunku do poprzednich badań, strukturę prezentowanych przez uczniów umiejętności percepcyjnych.

Tabela 2. Różnice dziewcząt i chłopców - badania 2016

\begin{tabular}{|c|c|c|c|c|c|}
\hline Podtesty & Płeć & $\mathbf{N}$ & M & SD & TEST $\mathrm{T}$ \\
\hline \multirow{2}{*}{ Część 1} & dziewczynka & 1351 & 8,71 & 2,35 & \multirow{2}{*}{$\begin{array}{l}\mathrm{t}=2,900 \\
\mathrm{df}=2725 \\
\mathbf{p}<\mathbf{0 , 0 0 4}\end{array}$} \\
\hline & chłopiec & 1376 & 8,45 & 2,32 & \\
\hline \multirow{2}{*}{ Część 2} & dziewczynka & 1351 & 6,07 & 1,95 & \multirow{2}{*}{$\begin{array}{l}\mathrm{t}=4,059 \\
\mathrm{df}=2725 \\
\mathbf{p}<\mathbf{0 , 0 0 0}\end{array}$} \\
\hline & chłopiec & 1376 & 5,76 & 1,98 & \\
\hline \multirow{2}{*}{ Częśćc 3} & dziewczynka & 1351 & 9,10 & 2,06 & \multirow{2}{*}{$\begin{array}{l}\mathrm{t}=8,406 \\
\mathrm{df}=2725 \\
\mathbf{p}<\mathbf{0 , 0 0 0}\end{array}$} \\
\hline & chłopiec & 1376 & 8,40 & 2,27 & \\
\hline \multirow{2}{*}{$\begin{array}{l}\text { Ogółem } \\
\text { TMUP }\end{array}$} & dziewczynka & 1351 & 23,88 & 4,35 & \multirow{2}{*}{$\begin{array}{c}\mathrm{t}=7,532 \\
\mathrm{df}=2725 \\
\mathbf{p}<\mathbf{0 , 0 0 0}\end{array}$} \\
\hline & chłopiec & 1376 & 22,62 & 4,41 & \\
\hline
\end{tabular}

Dwa pierwsze podtesty mierzą najbardziej pożądane z punktu widzenia dydaktyki muzycznej umiejętności percepcyjne: rozpoznawanie budowy formalnej utworów muzycznych, percepcji struktur wysokościowych, czasowych i harmonicznych, umiejętności dostrzegania tożsamości w przebiegu muzycznym oraz wrażliwości na styl w muzyce. $\mathrm{W}$ teście trzecim zadania diagnozują kojarzenie muzyki z treściami pozamuzycznymi oraz umiejętność rozróżniania barwy instrumentów i głosów ludzkich. Te ostatnie najczęściej bywają przyporządkowywane do edukacji muzycznej na poziomie elementarnym. I one na ogól, jeśli w ogóle, są realizowane przez nauczyciela wczesnej edukacji. Odniesienie się do zagadnień, które obejmują dwa pierwsze podtesty wydaje się zbyt trudne dla nauczycieli bez 
specjalistycznego przygotowania muzycznego. Można nawet zaryzykować twierdzenie, że większość nauczycieli pracujących z dziećmi na etapie początkowym nie ma świadomości istnienia tych zakresów. Wynika to na ogół z braków w ich wykształceniu spowodowanych minimalną ilością godzin edukacji muzycznej realizowanej w wyższych uczelniach ${ }^{4}$.

Odnotowanie różnicy w końcowej punktacji TMUP nie oddaje jak widać pełni informacji. Dopiero analiza wyników podtestów odsłania kierunek niekorzystnych zmian w muzycznej edukacji ostatnich lat. Ogranicza się ona, jeśli w ogóle się odbywa, do prostych zagadek słuchowych, poszukiwania muzycznych ilustracji dla otaczającej rzeczywistości bazującej na pozaszkolnych doświadczeniach dzieci. Wzrost wyników w tym zakresie (III podtest) z 63\% do blisko $68 \%$ wskazuje, iż w coraz większym stopniu wczesna edukacja muzyczna profiluje się na powyższe zadania. Znaczny spadek poziomów kompetencji (po 4 punkty procentowe) w pozostałych zakresach zdaje się potwierdzać zarysowany trend.

W aktualnych badaniach (2016) obydwie płci, mimo różnic międzygrupowych, w całym teście TMUP uplasowały się jednakowo - na poziomie 48 centyla ( $48 \%$ populacji uzyskuje wyniki niższe). Jest to dużo gorzej niż w latach poprzednich, gdzie dziewczęta osiągnęły 58 centyl (58\% populacji uzyskuje wyniki niższe), a chłopcy 57 centyl (57\% populacji uzyskuje wyniki niższe). Spadek poziomu wydaje się spektakularny kiedy uświadomimy sobie liczbę dzieci przypadającą na każdy centyl.

W odniesieniu do poszczególnych części porównanie przedstawia się następująco. Podtest pierwszy: dziewczęta 47 centyl obecnie, 47 centyl poprzednio; chłopcy 35 centyl obecnie, 51 centyl poprzednio. Podtest drugi: dziewczęta 43 centyl obecnie, 59 centyl poprzednio; chłopcy 50 centyl obecnie, 50 centyl wcześniej. Podtest trzeci: dziewczęta 52 centyl obecnie, 52 centyl obecnie; chłopcy 44 centyl obecnie, 44 centyl wcześniej.

Analiza wyników w odniesieniu do norm ogólnopolskich dla testu TMUP rzuca ciekawe światło na wyżej zaprezentowane analizy, z których wynikało, iż $\mathrm{w}$ trzecim podteście zarysowała się tendencja zwyżkowa. Ilustracja uzyskanych średnich arytmetycznych w odniesieniu do norm wskazuje na ten sam centyl. Natomiast w pozostałych zakresach potwierdzono wyraźne spadki.

Wszelkie zestawienia wykazują zatem, iż poziom muzycznych umiejętności percepcyjnych uczniów kończących trzecią klasę jest niezadowalający oraz uległ on obniżeniu w stosunku do badań z poprzednich lat, w których już obowiązywał zintegrowany model kształcenia. Wskazuje to na dalsze systematyczne obniżanie

\footnotetext{
${ }^{4}$ Bywają wyjątki od tej reguły
} 
statusu przedmiotu i jego znaczenia. Ale przede wszystkim wskazuje na wyhamowanie rozwoju muzycznego dziecka w wieku wczesnoszkolnym.

Tabela 3. Zestawienie wyników z roku 2016 z wynikami z roku 2007

\begin{tabular}{|l|c|c|c|c|}
\hline \multirow{2}{*}{$\begin{array}{c}\text { Część testu } \\
\text { TMUP }\end{array}$} & $\begin{array}{c}\text { Płeć } \\
\mathbf{D = 1 3 5 1}(\mathbf{n}) \\
\mathbf{C h}=\mathbf{1 3 7 6}(\mathbf{n})\end{array}$ & $\begin{array}{c}\text { Średnia } \\
\mathbf{z} \text { badań } \mathbf{2 0 0 7 \mathbf { r }} \\
\mathbf{n = 1 3 2 9}\end{array}$ & $\begin{array}{c}\text { Średnia } \\
\mathbf{z} \text { badań 2016 } \\
\mathbf{n = 2 7 2 7}\end{array}$ & $\mathbf{P}$ \\
\hline \multirow{2}{*}{ Część 1 } & $\mathrm{D}$ & 9,26 & 8,71 & $\mathbf{0 , 0 0 0}$ \\
\cline { 2 - 5 } & $\mathrm{Ch}$ & 9,15 & 8,45 & $\mathbf{0 , 0 0 0}$ \\
\hline \multirow{2}{*}{ Część 2 } & $\mathrm{D}$ & 6,59 & 6,07 & $\mathbf{0 , 0 0 0}$ \\
\hline \multirow{2}{*}{ Część 3 } & $\mathrm{Ch}$ & 6,21 & 5,76 & $\mathbf{0 , 0 0 0}$ \\
\hline \multirow{2}{*}{$\begin{array}{l}\text { Ogółem } \\
\text { TMUP 1, 2, 3 }\end{array}$} & $\mathrm{D}$ & 8,95 & 9,10 & $\mathbf{0 , 0 0 7}$ \\
\cline { 2 - 5 } & $\mathrm{Ch}$ & 8,49 & 8,40 & 0,153 \\
\hline
\end{tabular}

\section{RÓŻNICE POMIĘDZY WOJEWÓDZTWAMI}

Wnioski wynikające z analizy wyników uzyskanych przez uczniów w poszczególnych województwach należy formułować z wielką ostrożnością. I tak, zestawienia w zakresie podtestów wydają się w tym przypadku zbyt szczegółowe, choć oczywiście mają znaczenie diagnostyczne.

Tabela 4. Statystyki średniej i odchylenia standardowego uzyskane przez uczniów w poszczególnych województwach Polski

\begin{tabular}{|c|c|c|c|c|c|c|c|c|c|}
\hline \multirow{3}{*}{ Województwo } & \multirow{3}{*}{$\mathbf{N}$} & \multirow{2}{*}{\multicolumn{2}{|c|}{ Razem cz. 1}} & \multirow{2}{*}{\multicolumn{2}{|c|}{ Razem cz. 2}} & \multirow{2}{*}{\multicolumn{2}{|c|}{ Razem cz. 3}} & \multirow{2}{*}{\multicolumn{2}{|c|}{$\begin{array}{c}\text { Ogółem } \\
\text { TMUP }\end{array}$}} \\
\hline & & & & & & & & & \\
\hline & & M & $\mathrm{SD}$ & M & $\mathrm{SD}$ & M & $\mathrm{SD}$ & M & $\mathrm{SD}$ \\
\hline Dolnośląskie & 157 & 9,36 & 2,68 & 6,64 & 2,03 & 9,26 & 2,3 & 25,26 & 5,36 \\
\hline Kujawsko-pomorskie & 164 & 9,05 & 2,14 & 6,74 & 1,92 & 8,71 & 2,23 & 24,51 & 4,33 \\
\hline Lubelskie & 221 & 8,76 & 2,21 & 5,71 & 1,93 & 8,6 & 2,22 & 23,07 & 4,16 \\
\hline Lubuskie & 82 & 7,3 & 1,99 & 5,37 & 2,09 & 7,89 & 2,22 & 20,56 & 4,27 \\
\hline Łódzkie & 171 & 8,5 & 2,13 & 5,7 & 1,89 & 8,75 & 2,29 & 22,95 & 4,09 \\
\hline Małopolskie & 271 & 8,59 & 2,53 & 5,93 & 1,91 & 9,26 & 1,83 & 23,78 & 4,19 \\
\hline Mazowieckie & 316 & 8,69 & 2,23 & 5,78 & 2,04 & 8,74 & 2,58 & 23,22 & 4,61 \\
\hline Opolskie & 87 & 8,22 & 2,58 & 5,91 & 2,14 & 8,08 & 2,16 & 22,21 & 5,23 \\
\hline Podkarpackie & 223 & 8,57 & 2,43 & 5,89 & 1,94 & 8,9 & 2,03 & 23,36 & 4,31 \\
\hline
\end{tabular}




\begin{tabular}{|l|c|c|c|c|c|c|c|c|c|}
\hline Podlaskie & 105 & 8,9 & 2,17 & 5,7 & 1,73 & 9,17 & 1,89 & 23,77 & 3,52 \\
\hline Pomorskie & 144 & 8,18 & 2,51 & 5,83 & 1,81 & 8,72 & 2,12 & 22,73 & 4,58 \\
\hline Śląskie & 297 & 8,56 & 2,15 & 5,54 & 1,92 & 8,78 & 2,2 & 22,88 & 4,19 \\
\hline Świętokrzyskie & 132 & 8,61 & 2,29 & 5,97 & 1,86 & 8,52 & 2,99 & 23,11 & 4,17 \\
\hline Warmińsko-mazurskie & 128 & 8,29 & 2,35 & 5,84 & 1,98 & 8,61 & 2,32 & 22,74 & 4,26 \\
\hline Wielkopolskie & 275 & 8,3 & 2,27 & 6,13 & 2,04 & 8,44 & 2,15 & 22,87 & 4,3 \\
\hline Zachodniopomorskie & 90 & 8,41 & 2,63 & 5,71 & 1,87 & 8,18 & 2,16 & 22,3 & 4,35 \\
\hline
\end{tabular}

Tak się składa, że najwyższe osiągnięcia (województwo dolnośląskie) uczniowie prezentują jednocześnie - w całym teście oraz jego poszczególnych zakresach. Podobnie jest w przypadku wyniku najsłabszego (województwo lubuskie). Ta niewielka, jak by się wydawało, różnica pomiędzy najsłabszym i najwyższym końcowym wynikiem wynosząca tylko 4,7 punktów daje różnicę aż 35 centyli. Tak więc dziecko prezentujące przeciętny poziom kompetencji muzycznych z województwa dolnośląskiego znajdzie się na poziomie 58 centyla (jeśli jest dziewczynką) a dziecko zamieszkujące województwo lubuskie prezentujące również przeciętny poziom kompetencji znajdzie się na poziomie 23 centyla. Nie dysponujemy na tym etapie danymi, które pozwoliłyby na rzetelne poszukiwanie przyczyn zilustrowanego stanu rzeczy.

Ciekawostkę stanowi wysoki poziom w zakresie trzeciego podtestu uzyskany w dwóch województwach: podlaskim i małopolskim. Odnosi się on wyłącznie do zadań testujących najbardziej typowe szkolne treści. Z pewnością świadczy o rzetelnej pracy nauczycieli, jednak także o charakterystycznym „sprofilowaniu” muzycznej edukacji (o czym w dalszej części artykułu).

Warto odnotować również najwyższy wynik uzyskany w drugim podteście przez uczniów z województwa kujawsko-pomorskiego. Oscyluje on w granicach 59-66 centyla (w zależności od płci). Ta część testu zawiera zadania wymagające umiejętności rozpoznawania tożsamości w przebiegu muzycznym i nawet uczniom ze szkół muzycznych sprawia, w tym wieku, kłopoty. Co ciekawe, ci sami uczniowie wypadli dość przeciętnie w podteście trzecim diagnozującym najbardziej typowe muzyczne umiejętności. Jednak ich równie wysoki poziom osiągnięć w podteście pierwszym niewątpliwie ostatecznie wskazuje na kompetentny poziom realizacji zajęć muzycznych w badanych klasach. Może również wskazywać na duże muzyczne percepcyjne doświadczeniu dzieci, co już niekoniecznie wiąże się ze szkołą.

Wykazany w badaniach brak różnic w zakresie trzeciego podtestu pomiędzy uczniami ze wsi oraz małych i dużych miast potwierdza uwagi o charakterystycznym ograniczeniu (z punktu widzenia dydaktyki muzyki), czyli typowym „sprofilowaniu” edukacji muzycznej na etapie początkowym. 


\section{MUZYCZNE WYKSZTAŁCENIE NAUCZYCIELA A WYBRANE ZALEŻNOŚCI}

Formalne wykształcenie muzyczne nauczycieli stanowi ważną determinantę kompetencji muzycznych uczniów (Weiner 2010, s. 321). W aktualnych badaniach dotyczy ono niewielkiego odsetka uczniów i nauczycieli (12\%). Stąd, być może, zarysowała się jedynie tendencja (w dwóch podtestach i ogólnym wyniku) a brak jest istotnych statystycznie różnic.

Nieco światła na powyższy obraz rzuca analiza zależności pomiędzy deklarowaną aktywnością muzyczną uczniów a kompetencjami formalnymi nauczycieli. Okazuje się, iż mimo braku istotnej różnicy pomiędzy grupami prowadzonymi przez tych nauczycieli uwidacznia się odwrotnie proporcjonalna tendencja. Uczniowie, których uczą nauczyciele bez formalnego wykształcenia deklarowali wyższą aktywność muzyczną $(M=16,18)$ niż ich koledzy z przeciwnej grupy $(M=16,03)$. Zbyt mała liczba takich klas nie pozwoliła jednak na uzyskanie istotnej różnicy. Być może jest tak, iż to właśnie podejmowana przez uczniów muzyczna aktywność (wymuszona sztampowymi, nie zapewniającymi potrzeb dzieci, lekcjami muzyki) równoważy w pewnym stopniu brak kompetencji formalnych nauczycieli, przyczyniając się do wyższych wyników w TMUP a tym samym braku istotnej różnicy pomiędzy badanymi grupami.

Tabela 5. Korelacje pomiędzy TMUP a poziomem deklarowanej aktywności muzycznej

ADM u uczniów w dwóch grupach nauczycieli

\begin{tabular}{|c|c|c|c|c|c|c|}
\hline $\begin{array}{c}\text { Razem } \\
\text { cz.1 }\end{array}$ & Korelacje & & Razem cz. 2 & Razem cz. 3 & $\begin{array}{c}\text { Ogółem TMUP } \\
\text { cz. 1, 2, } 3\end{array}$ & $\begin{array}{c}\text { Deklarowana } \\
\text { aktywność } \\
\text { muzyczna ADM }\end{array}$ \\
\hline & Razem cz. 1 & $\mathrm{r}$ &, $183^{* *}$ &, $198^{* *}$ &, $707^{\star *}$ & $136^{\star \star}$ \\
\hline & & $\mathrm{p}$ & ,000 & ,000 & ,000 &, 000 \\
\hline & & $\mathrm{n}$ & 2383 & 2383 & 2383 & 2383 \\
\hline, $232^{\star *}$ & Razem cz. 2 & $\mathrm{r}$ & & $196^{\star *}$ &, $639^{\star *}$ &, $126^{\star *}$ \\
\hline 000 & & $\mathrm{p}$ & & ,000 &, 000 &, 000 \\
\hline 480 & & $\mathrm{n}$ & & 2383 & 2383 & 2383 \\
\hline, $190^{* *}$ & Razem cz. 3 & $\mathrm{r}$ &, $121^{* *}$ & &, $689^{\star *}$ &, $163^{\star \star}$ \\
\hline, 000 & & $\mathrm{p}$ & ,008 & & ,000 & , 000 \\
\hline 480 & & $\mathrm{n}$ & 480 & & 2383 & 2383 \\
\hline, $732^{\star *}$ & $\begin{array}{l}\text { Ogółem } \\
\text { TMUZ 1, 2, } 3\end{array}$ & $\mathrm{r}$ &, $628^{* *}$ &, $658^{\star *}$ & &, $209^{\star *}$ \\
\hline, 000 & & $\mathrm{p}$ &, 000 &, 000 & &, 000 \\
\hline 480 & & $\mathrm{n}$ & 480 & 480 & & 2383 \\
\hline
\end{tabular}




\begin{tabular}{|c|l|c|c|c|c|c|}
\hline $\mathbf{2 0 0}$ & $\begin{array}{l}\text { Deklarowana } \\
\text { aktywność } \\
\text { muzyczna } \\
\text { ADM }\end{array}$ & $\mathrm{r}$ & $\mathbf{, \mathbf { 1 5 0 } ^ { * * }}$ & $\mathbf{, \mathbf { 1 7 5 } ^ { * * }}$ & $\mathbf{, 2 6 1 ^ { * * }}$ & \\
\hline, 000 & & $\mathrm{p}$ &, 001 &, 000 &, 000 & \\
\hline 480 & & $\mathrm{n}$ & 480 & 480 & 480 & \\
\hline
\end{tabular}

Górna macierz korelacji uczniowie, których nauczyciele nie mają kompetencji muzycznych

Dolna macierz korelacji uczniowie, których nauczyciele mają kompetencje muzyczne

${ }^{* * *}$ - poziom istotności $\mathrm{p}<0,001,{ }^{* *}$ poziom istotności $\mathrm{p}<0,005$

\section{AKTYWNOŚĆ MUZYCZNA UCZNIÓW}

Analiza deklarowanej aktywności muzycznej badanych wykazała, iż dziewczynki częściej i chętniej działają muzycznie $(M=18,48 ; S D=5,94)$ niż chłopcy $(M=13,90$; $\mathrm{SD}=13,90)$. Różnica jest bardzo istotna statystycznie (test t dla prób niezależnych). Wynik ten nie zaskakuje w świetle osiągnięć w zakresie TMUP. Wcześniej bowiem w badaniach notowano istotny, wprost proporcjonalny związek pomiędzy aktywnością muzyczną a percepcyjnymi umiejętnościami muzycznymi (Weiner 2010, s. 332-336)

Podział na województwa potwierdza obraz uzyskanych wcześniej relacji. Okazuje się, że tam gdzie dzieci chętniej aktywizują się muzycznie, uzyskują wyższe wyniki testowe. I odwrotnie.

Podobnie układają się osiągnięcia w odniesieniu do miejsca zamieszkania. Dzieci z miast wykazują największy zapał do działań muzycznych, co pokrywa się z poziomem ich kompetencji muzycznych. Nie dotyczy to jednak mieszkańców miast wojewódzkich. Być może w tym przypadku przyczyna leży w fakcie zwiększonej podaży konkurencyjnych atrakcji, spośród której uczniowie mogą wybierać.

Wyjątkowo ciekawa okazała się szczegółowa analiza rodzaju podejmowanej przez dzieci aktywności. Okazało się, iż 9-latki najczęściej słuchają muzyki, a zdecydowana większość z nich nie czyta o wydarzeniach muzycznych, nie bywa na koncertach, nie traktuje muzyki jako tworzywa twórczego oraz nie marzy o tym aby nauczyć się gry na jakimś instrumencie. Blisko $40 \% \mathrm{z}$ nich nigdy albo bardzo rzadko śpiewa, tańczy i porusza się przy muzyce.

Z badania wyłania się obraz dzieci, których profil kontaktu z muzyką nie jest typowy dla wieku. Bardziej przypomina preferencje nastolatka lub osoby dorosłej. Tego rodzaju dane powinny szczególnie zwrócić uwagę dydaktyków muzyki oraz władz oświatowych. 


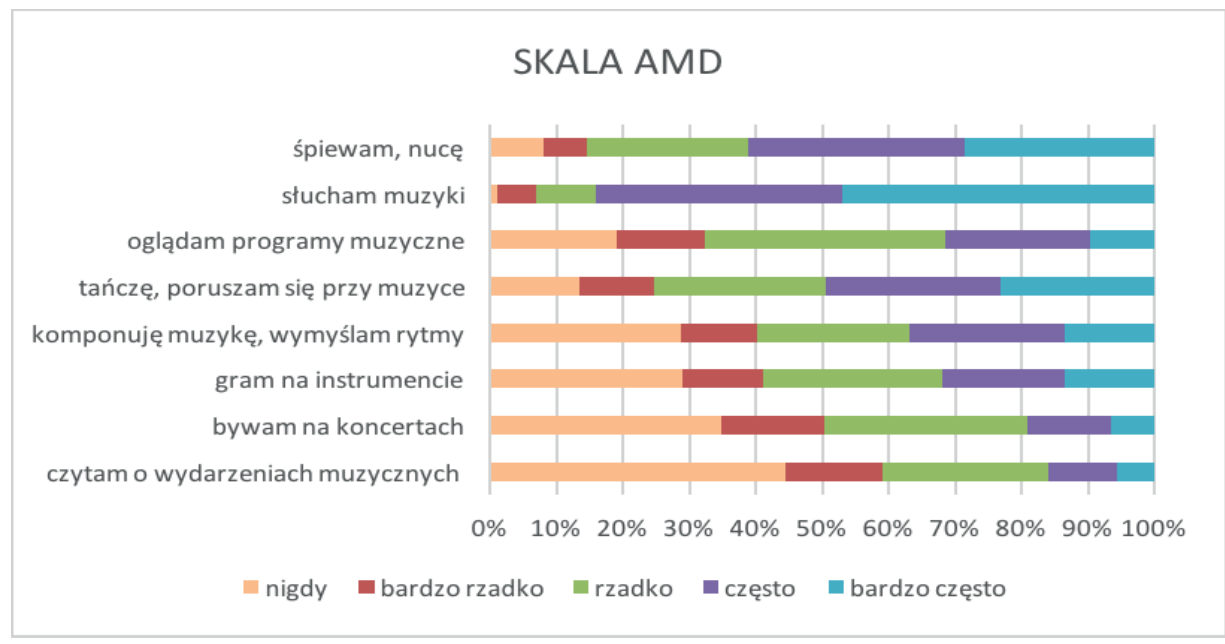

Rysunek 1. Wykres skumulowany odpowiedzi udzielonych na skali AMD.

Zasoby osobiste nauczycieli

Badani nauczyciele wczesnej edukacji stanowią grupę wyselekcjonowaną z terenu całej Polski. Zdecydowana ich większość pracuje w zawodzie ponad 16 (23\%) lub nawet ponad 26 lat (56\%). Znają więc oni doskonale warunki realizacji programu kształcenia w modelu przedmiotowym. W tym badaniu ma to kluczowe znaczenie.

Do 1999 roku (a więc w modelu przedmiotowym) muzyka była jednym z obowiązkowych przedmiotów w I etapie kształcenia a nauczyciele realizowali treści na podstawie obligatoryjnego programu kształcenia opracowanego na naukowych podstawach (Przychodzińska 1989) - jednakowego dla uczniów w całym kraju (Program nauczania początkowego 1983). Ci nauczyciele nabyli więc w praktyce dobrych doświadczeń, a przynajmniej mieli taką szansę.

Ponadto, biorąc pod uwagę ich wiek metrykalny i poziom wykształcenia można przypuszczać, iż ukończyli jednolite pięcioletnie studia magisterskie w zakresie wczesnej edukacji. A w programie tych studiów przygotowanie muzyczne stanowiło ważny element. Studenci realizowali tzw. zajęcia umuzykalniające, które uzupełniały ich podstawowe umiejętności i dopiero na bazie takich zajęć uczyli się metodyki przedmiotu. Obecnie możemy tylko pomarzyć o powyższym rozwiązaniu. Warto także przypomnieć, iż w tamtych latach na studia w zakresie wczesnej edukacji obowiązywał egzamin, w czasie którego eliminowano z dalszego procesu rekrutacyjnego osoby monotoniczne.

Tak więc, mimo iż badana przez nas grupa nauczycieli właściwie nie posiada dodatkowego formalnego wykształcenia muzycznego (15 osób zgłosiło ukończenie muzycz- 
nych szkół różnego typu), to ich długa praktyka zawodowa (80\% to nauczyciele dyplomowani) zawiera elementy, które na użytek naszych badań można by nazwać wzorcowymi.

Aktywność muzyczna, tak ważna dla pedagoga muzyki (niezależnie od etapu na którym uczy) nie stanowi mocnej strony badanych. Ich profil nie wyróżniałby się na tle przeciętnego Polaka. Tylko 7 osób spośród 150 badanych ocenia swoje umiejętności gry na instrumencie jako zawansowane. Brak zaangażowania w działania muzyczne przekazują uczniom - tylko 27\% nauczycieli raz w miesiącu uczestniczy ze swoją klasą w wydarzeniach artystycznych. Pozostali robią to raz w roku lub rzadziej, a blisko 10\% przyznaje, że nigdy (Weiner, Waluga i in. 2016).

Rozpoznanie preferencji swoich uczniów odnośnie działań muzycznych pokrywa się z deklaracjami dzieci. Świadczy to wprawdzie pozytywnie o kompetencjach diagnostycznych nauczycieli. Ale nie do końca zachwyca. Słuchanie muzyki i zbiorowy śpiew to nie są jedyne aktywności, które dzieci w tym wieku powinny realizować, a kto, jeśli nie nauczyciel, ma im otwierać świat muzyki jakiego nie znają? A jeśli nie znają - jak mogą polubić?

Równocześnie ci sami pedagodzy (ponad 80\% badanych) widzą sens w częstym podejmowaniu muzycznej aktywności. Otwartym pozostaje pytanie - czym chcą zająć wychowanków na tych lekcjach?

Piosenki, główna atrakcja wczesnej edukacji muzycznej w Polsce, uczone są przez większość nauczycieli (54\%) sztampowo i niepoprawnie. Dobrze, że wspomagają ten proces różnymi instrumentami. Choć raczej tylko deklarują ich wykorzystanie, ponieważ ich wypowiedzi wydają się niespójne z wcześniejszymi stwierdzeniami, dotyczącymi prezentowanego poziomu umiejętności gry na instrumentach (np. 82 \% badanych deklaruje, iż nie gra na gitarze, a 32\% rzekomo wykorzystuje ją przy nauce piosenek?!).

Tabela 6. Deklarowane przez badanych nauczycieli poziomy gry na instrumentach

Czy potrafi Pani/Pan grać na instrumencie muzycznym?

\begin{tabular}{|c|c|c|c|}
\hline \multicolumn{2}{|c|}{ Tak } & \multicolumn{2}{c|}{ Nie } \\
\hline $\mathrm{n}$ & $\%$ & $\mathrm{n}$ & $\%$ \\
\hline 92 & 61,3 & 58 & 38,7 \\
\hline
\end{tabular}

\begin{tabular}{|l|c|c|c|c|c|c|c|c|}
\hline \multirow{2}{*}{ Skala } & \multicolumn{2}{|c|}{ Fortepian } & \multicolumn{2}{c|}{ Gitara } & \multicolumn{2}{c|}{ Flet } & \multicolumn{2}{c|}{ Inne } \\
\cline { 2 - 10 } & $\mathrm{n}$ & $\%$ & $\mathrm{n}$ & $\%$ & $\mathrm{n}$ & $\%$ & $\mathrm{n}$ & $\%$ \\
\hline O: nie gram & 99 & 66,0 & 123 & 82,0 & 78 & 52,0 & 125 & 83,2 \\
\hline 1: początkujący & 24 & 16,0 & 12 & 8,0 & 27 & 18,0 & 6 & 4,0 \\
\hline $\mathbf{2}$ & 12 & 8,0 & 4 & 2,7 & 13 & 8,7 & 5 & 3,4 \\
\hline $\mathbf{3}$ & 7 & 4,7 & 7 & 4,7 & 18 & 12,0 & 6 & 4,0 \\
\hline $\mathbf{4}$ & 8 & 5,3 & 3 & 2,0 & 11 & 7,3 & 5 & 3,4 \\
\hline 5: zaawansowany & 0 & 0,0 & 1 & 0,7 & 3 & 2,0 & 3 & 2,0 \\
\hline
\end{tabular}


Warto pochylić się nad czynnikami utrudniającymi, zdaniem nauczycieli, edukację muzyczną. Brak instrumentów muzycznych lub słaba ich jakość stanowi kluczowy argument - wskazuje na ten element blisko 90\% badanych. Jak się ma to jednak to faktu braku umiejętności gry na instrumencie? Blisko połowa stwierdziła, że nie potrafi wykorzystać na lekcji nawet fletu sopranowego. Po co więc nauczycielom instrumenty?

Duża grupa narzeka na brak odpowiednich opracowań repertuarowych, z czym trudno się zgodzić znając dobrze rynek wydawniczy. Natomiast trzeba przyznać, że wiele wartościowych pozycji wydanych przed wielu laty jakoś nie może doczekać się wznowień.

Zdecydowana większość kadry nauczycielskiej deklaruje potrzebę uczestnictwa w kursach dokształcających i szkoleniach. Ten argument nie do końca przekonuje. Oferowane przez uczelnie kursy i szkolenia nie cieszą się popularnością jeśli nie dają kwalifikacji. A właśnie takie są z powyższego zakresu proponowane

Cieszy natomiast postulat dużej grupy badanych (blisko 60\%) dotyczący zwiększenia ilości godzin przeznaczanych na realizację edukacji muzycznej. Tu jednak wyjście jest bardzo proste. Nikt przecież obecnie nie narzuca nauczycielom jak mają podzielić swój dzień pracy. Mogą to robić według własnych preferencji, potrzeb i wiedzy. Zawsze z pożytkiem dla uczniów.

Dziwi natomiast argument zróżnicowania zdolności muzycznych uczniów w klasie jako przyczyna trudności w realizacji edukacji muzycznej. To trochę tak, jakby nauczyciele narzekali, iż w pierwszej klasie nie mają wyłącznie uczniów płynnie czytających i liczących biegle co utrudnia im realizację programu. Podstawową ideą, którą współczesny pedagog powinien zaakceptować jest właśnie fakt istnienia różnic pomiędzy uczniami.

Tabela 7. Czynniki utrudniające realizację muzyki w opinii badanych nauczycieli

\begin{tabular}{|l|c|c|}
\hline \multirow{2}{*}{ Czynniki utrudniające wspomaganie realizacji zadań muzycznych } & \multicolumn{2}{c|}{ Odpowiedzi } \\
\cline { 2 - 3 }$\%$ & $\mathbf{N}$ & 11,5 \\
\hline Brak instrumentów & 45 & 22,3 \\
\hline Niedostateczna liczba instrumentów dla całej klasy & 87 & 8,2 \\
\hline Niska jakość instrumentów & 32 & 9,7 \\
\hline Brak odpowiednio opracowanego repertuaru szkolnego & 38 & 17,9 \\
\hline Brak odpowiednich kursów i szkoleń muzycznych dla nauczycieli & 70 & 1,5 \\
\hline Brak możliwości korzystania przez nauczyciela z kursów i szkoleń muzycznych & 6 & 14,8 \\
\hline Zbyt mała liczba godzin przeznaczona na zajęcia muzyczne & 58 & 11,5 \\
\hline Znaczne zróżnicowanie zdolności muzycznych uczniów w klasie & 45 & 2,6 \\
\hline Inne, jakie? & 10 & \\
\hline
\end{tabular}


Z badań wynika także, że nauczyciele akceptują powszechnie proponowane im podręczniki i uważają je za użyteczne dla muzycznej edukacji. Niestety, muzyka w nich najczęściej ogranicza się do kilku piosenek, zabaw ruchowych, prostych informacji i zagadek (Weiner 2008).

Mimo opisanych wyżej trudności, blisko połowa badanych przywiązana jest do osobistej realizacji muzyki i nie oddałaby tych zajęć specjaliście muzykowi.

Analiza zależności pomiędzy wydzielonymi zmiennymi w zakresie zasobów osobistych nauczycieli wykazała istnienie wprost proporcjonalnego związku pomiędzy poszczególnymi elementami kompetencji. Oznacza to, iż nauczyciel formalnie wykwalifikowany muzycznie to jednocześnie ten, który wyżej ocenia swoje kompetencje i doświadczenie, lepiej radzi sobie na lekcjach i odczuwa wyższą satysfakcję zawodową. Wydaje się to oczywiste, jednak w kontekście uzyskanych wyników należy zadać pytanie o tych, którzy nie mają formalnego przygotowania. Czy ich niska samoocena i satysfakcja zawodowa nie będzie przekładać się na trudności w zainteresowaniu uczniów muzyką? Niepewność swojej roli, brak pomysłów metodycznych, sztampowe działania, brak poczucia sprawstwa na zajęciach muzycznych muszą przynieść określone efekty. Nie te jednak, których oczekiwalibyśmy.

\section{PODSUMOWANIE}

Kompetencje muzyczne uczniów w wieku wczesnoszkolnym nie powinny być niższe od adekwatnych dla wieku możliwości rozwojowych. Ich poziom, jak wiemy, zależy od wielu czynników. Za najistotniejszy należy uznać aktywność własną podmiotu (Weiner 2010, s. 345-359). I tu, w przypadku małych dzieci, pojawia się wielka odpowiedzialność rodziców i nauczycieli. O ile na działania rodzicielskie mamy ograniczony wpływ, to efekty pracy szkoły powinny podlegać rzetelnemu monitoringowi.

Jak wskazują wyniki przedstawionych badań istnieje wiele płaszczyzn wymagających pilnej interwencji. Kompetencje muzyczne dzieci kończących trzecie klasy szkoły podstawowej są niezadowalające a profil aktywności muzycznej jaką prezentują nie stwarza szansy na harmonijny rozwój muzycznego potencjału. Kto, jeśli nie nauczyciel powinien w takiej sytuacji interweniować?

Spotkanie pedagoga, który otworzy uczniom świat muzyki, nauczy czerpnia radości z kontaktu z wieloma jej płaszczyznami, potrafi wykorzystać jej potencjał do stymulowania ogólnego rozwoju powinno być tym, co przytrafi się każdemu pełnemu ciekawości poznawczej dziecku. Nie dokona tego nauczyciel niepewny 
swej wiedzy, korzystający wyłącznie z najprostszych podręcznikowych rozwiązań, nie interesujący się muzyką i unikający muzycznej aktywności.

Na podjętą przez Instytut Muzyki i Tańca diagnozę poziomu kompetencji muzycznych dzieci w wieku wczesnoszkolnym i ich wybranych determinant można patrzeć jak na akt twórczy, którego najprostszą charakterystykę stanowi stawianie pytań i poszukiwanie na nie odpowiedzi. Akt ten zaowocował niezwykle istotnym, ze względu na ogólnopolski zasięg badań, argumentem na rzecz zmiany sytuacji edukacji muzycznej w początkowym etapie kształcenia. Odwołując się do słów I. Wojnar warto pamiętać, że badacz, jako jednostka twórcza, poszukując odpowiedzi oddziałuje nie tylko na świat zewnętrzny, który rozpoznaje i zmienia ale także na samego siebie (Wojnar 2000, s.205). Być może to właśnie ta zależność wciąż zachęca nas do stawiania nowych pytań i poszukiwania kolejnych wyzwań twórczych.

\section{LITERATURA}

Burowska Z., J. Kurcz J., Wilk A., 1997, Badania nad skutecznością metod wychowania muzycznego w szkolnictwie ogólnokształcącym. W: A. Białkowski (red.), Edukacja estetyczna w perspektywie przemian szkoły współczesnej, Lublin, Wydawnictwo UMCS.

Dyląg J., 1994, Kształcenie umiejętności dydaktycznych studentów do nauczania muzyki w klasach I-III. W: Z. Burowska, J. Kurcz (red.), Krakowska Koncepcja Wychowania Muzycznego. Kraków, Wydawnictwo AM.

Hoffman-Lipska E., Żychowska T., 1997, Próba diagnozy stanu powszechnego wychowania muzycznego w szkołach podstawowych. W: Edukacja estetyczna w perspektywie przemian szkoły współczesnej. A. Białkowski (red.), Lublin, Wydawnictwo UMCS. Jaworska A., 1999, Osiągnięcia uczniów klas I-III w zakresie muzyki. W: M. Cackowska (red.) Skuteczność nauczania początkowego w Polsce 1976-1990. Lublin, Wydawnictwo UMCS.

Kamińska B., 2016, Kompetencje muzyczne -ich miejsce i znaczenie we wczesnej edukacji muzycznej. W: H. Tomasz-Plewa, I. Polak (red.), Wczesna edukacja muzyczna. Rozważania, propozycje, badania. Wrocław, Wydawnictwo AMKL.

Program nauczania początkowego, klasy I-III, 1983, Ministerstwo Oświaty i Wychowania, Instytut Programów Szkolnych. Warszawa,WSiP.

Przychodzińska M., 1989, Wychowanie muzyczne - idee, treści, kierunki rozwoju. Warszawa, WSiP

Rakowski A., 2010, Powszechna edukacja muzyczna - historia narodowego niepowodzenia. W: A. Białkowski, M. Grusiewicz, M. Michalak (red.), Edukacja muzy- 
czna w Polsce. Diagnozy, debaty, aspiracje. Warszawa, Wydawnictwo Fundacja „Muzyka jest dla wszystkich”.

Rozporządzenie Ministra Nauki i Szkolnictwa Wyższego z dnia 8 sierpnia 2011 r. w sprawie obszarów wiedzy, dziedzin nauki i sztuki oraz dyscyplin naukowych i artystycznych, Dz.U. 2011 nr 179 poz. 1065.

Sacher W., 2004 (red.) Zdolności muzyczne dzieci w wieku 5-13 lat w opinii nauczycieli a wyniki badań testowych. Mysłowice, Wydawnictwo GWSP.

Suświłło M., 2001, Psychopedagogiczne uwarunkowania wczesnej edukacji, Olsztyn, Wydawnictwo UWM.

Weiner A, Waluga A., Migdał-Najman K., Ostafińska-Molik B., Delecka-Bury A., 2016, Kompetencje muzyczne absolwentów I etapu edukacyjnego podstawowych szkół ogólnokształcących i ich wybrane determinanty. Raport z badań. Warszawa, Wydawnictwo IMiT.

Weiner A., 2000, Aktywność muzyczna w zintegrowanym systemie kształcenia wczesnoszkolnego. W: V Przerembska (red.) Treści, formy i metody przedmiotu „Muzyka” w świetle reformy powszechnej edukacji. Łódź, Wydawnictwo UŁ.

Weiner A., 2004, Nie ta melodia. Edukacja wczesnoszkolna po I etapie reformy edukacja muzyczna w kształceniu zintegrowanym. „Życie Szkoły” nr 10.

Weiner A., 2006, Wczesna edukacja muzyczna - obszar zaniedbany czy zaniechany? W: M. Suświłło (red.) Zaniedbane i zaniechane obszary edukacji w szkole. Olsztyn, Wydawnictwo UWM.

Weiner A., 2008, „Muzyka” w zintegrowanych ofertach programowych - studium porównawcze. W: R. Gozdecka, M. Grusiewicz (red.) Współczesne oblicza edukacji muzycznej. Lublin, Wydawnictwo UMCS.

Weiner A., 2007, Test Muzycznych Umiejętności Percepcyjnych. Podręcznik. Lublin, Wydawnictwo UMSC.

Weiner A., 2010, Kompetencje muzyczne dzieci w młodszym wieku szkolnym - determinanty, zależności, perspektywy rozwoju. Lublin, Wydawnictwo UMCS..

Wojnar I, 2000, Samowychowanie - humanistycznym wyborem człowieka. W: I. Wojnar Humanistyczne intencje edukacji. Warszawa, Wydawnictwo Akademickie Żak.

Zwolińska E., 1997 (red.) Sposoby kierowania rozwojem muzycznym dziecka w wieku przedszkolnym i wczesnoszkolnym. Bydgoszcz, Wydawnictwo AB. 
THE STUDY AS A CREATIVE ACT - REFLECTIONS ON THE MARGINS OF THE REPORT FROM THE NATIONWIDE RESEARCH ON THE MUSICAL COMPETENCE OF THE GRADUATES OF THE FIRST STAGE OF EDUCATION

\begin{abstract}
The article presents a research analysis in relation to the results of the largest so far project recently completed in Poland, diagnosing the musical competence of early school pupils. From the perspective of the Project Leader, the author interprets the obtained results in the context of the multiannual trends, whilst she treats the research itself as a creative act, whose beginning constitutes a question, and the end - an understanding.
\end{abstract}

Key words: Early school education, musical competence, study as a creative act 